- civilian nuclear plants, and offers assistance in times of crisis.

The WHO, in contrast, has an explicit remit to provide information during natural outbreaks of disease that spread across borders. This means that nations in a threatened region are eager for its expert assessments, says Duncan Snidal, a expert in international relations at the University of Oxford, UK. The IAEA, in comparison, actively probes the nuclear endeavours of members, including any undeclared weapons programmes, so they are reluctant to give it too much authority.

Nowhere has the IAEA's short leash been more apparent than in its International Nuclear and Radiological Event Scale. The agency introduced the numerical severity scale in 1990 to facilitate quick communication about nuclear accidents, but, bizarrely, it is national regulators that determine the rating of a particular emergency. Japan initially ranked the Fukushima crisis at level 5 by treating each reactor at the plant as a separate event, but a month after the event it grouped the reactors into a single incident and upped the rating to 7 , the highest on the scale. The sudden change created confusion in the press and anxiety for the public, and showed just how inadequate the scale is, says Jeffrey Lewis, director of the East Asia nonproliferation programme at the James Martin Center for Nonproliferation Studies in Washington DC.

\section{A NUCLEAR MINNOW}

The IAEA has relatively limited resources compared with the United Nations agencies for food and health security.

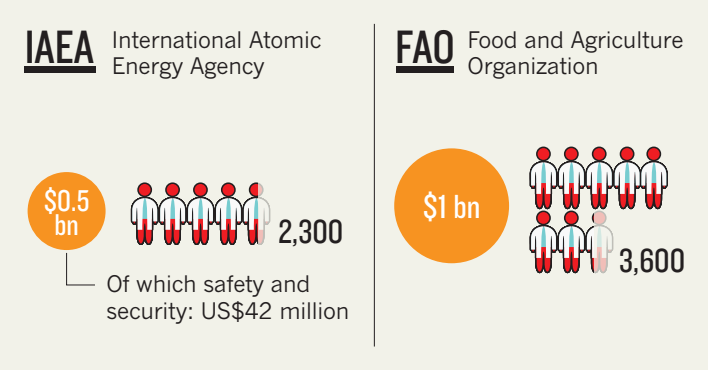
FAO Food and Agriculture

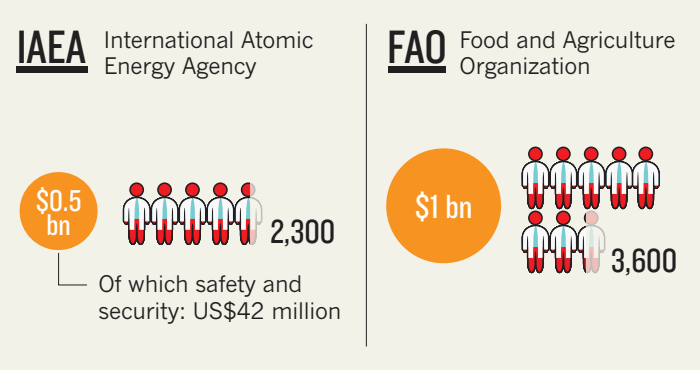

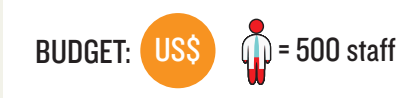

Whether the IAEA can gain more independence to assess nuclear accidents is uncertain, but its emergency scale is very likely to be revisited given the confusing way in which it has been used. Some commentators have also called for a stronger IAEA that can enforce global safety standards or take control in an emergency, but Acton labels such ideas "insane". Nations might begin to feel that "safety is not our responsibility", he says. Moreover, a nuclear plant's operators are often better placed to handle a crisis than are outside officials unfamiliar with the facility. In any event, Acton doubts that countries will abdicate oversight of their reactors. "The whole thing is fanciful," he says.
Lewis says that a more outspoken IAEA could have dispelled some of the confusion around the impact of Fukushima. Japanese authorities played down the severity of the accident, for example, while US regulators on the scene described a much more frightening worst-case scenario. But if the IAEA is just one more voice in the tumult, "and if it is incompetent, then it makes everything much, much worse", Lewis adds.

It will ultimately be up to the member states to determine how much independence the IAEA will have in a future crisis. The agency's own position is unknown: it declined Nature's interview request for this story. — SEE EDITORIAL P.389

\title{
Is FutureGen betting on the wrong rock?
}

\section{Commercial rival says gas spreading and leakage could harm US carbon-sequestration effort.}

\section{BY JEFF TOLLEFSON}

$\mathrm{K}$ urt Zenz House watches from a corner office in Berkeley, California, as carbon dioxide is pumped into sandstone 2,000 metres below the southern Illinois farmland. A colourful plume grows on his computer screen, modelling the movement of $\mathrm{CO}_{2}$ through the porous rock. As decades elapse in the simulation, the $\mathrm{CO}_{2}$ rises and settles under the dome of shale that caps the formation.

House says that this is exactly what should happen. " $\mathrm{CO}_{2}$ injected anywhere inside the geological boundary will stay within the boundary," he says. And, he argues, that is exactly what won't happen when FutureGen 2.0, the US government's main commercial demonstration project for carbon capture and sequestration (CCS), begins to store $\mathrm{CO}_{2}$ from a coal-fired power plant in Illinois in 2015 .

House's company, C12 Energy in Berkeley, is challenging the strategy that the project has chosen for sequestering the 1.3 million or so tonnes of $\mathrm{CO}_{2}$ that it aims to capture each year. In its demonstration effort, FutureGen intends to inject the $\mathrm{CO}_{2}$ into porous sandstone with no dome or other structure to help trap the gas - arguing in part that such formations are too rare to rely on for large-scale storage. But C12 and its backers, who advocated a rival site, say that the strategy risks legal and financial problems if the $\mathrm{CO}_{2}$ spreads farther than expected.

Last February, FutureGen rejected C12's bid to handle the storage side of the project, so $\mathrm{C} 12$ is pushing ahead with plans to develop its own commercial sequestration operation. It is acquiring rights to pump $\mathrm{CO}_{2}$ into its Illinois site - a domed reservoir in Fayette County 160 kilometres from the plant (see 'Tilted playing field') - and into reservoirs in eight other states in the hope that CCS will eventually become commonplace at other power plants.

Killed by US President George W. Bush in 2008, FutureGen was resurrected a year later by President Barack Obama as a centrepiece of his administration's strategy for climate change and energy. The project is a US\$1.3-billion deal between the US Department of Energy and a group of major energy companies to capture and store $\mathrm{CO}_{2}$ from the exhaust of a coal plant near Meredosia, Illinois. After rejecting C12's bid, FutureGen settled on a saline aquifer 1,200-1,500 metres deep in Morgan County, where the plant is located.

As well as lacking a structural trap, the sandstone in Morgan County sits at a slight angle and is shallower than that in Fayette County. All of this makes gas injected there likely to be more mobile and less predictable, says Daniel Schrag, a geochemist at Harvard University in Cambridge, Massachusetts. That could "poison the well" for CCS if legal problems ensue, says Schrag, who was House's $\mathrm{PhD}$ adviser and now chairs C12's board of science advisers. 
By trapping the injected $\mathrm{CO}_{2}$ with geological structures, $\mathrm{C} 12$ says that it can minimize the number of leases for subsurface rights it needs to negotiate with landowners. In its bid, submitted in partnership with local governments, the company had offered to charge a flat fee of $\$ 140$ million to handle everything at the storage site. The pipeline to carry the $\mathrm{CO}_{2}$ from the plant would have cost another $\$ 100$ million to $\$ 200$ million. FutureGen initially declined to talk about finances, saying only that the project would come in at or below budget. It now says that its approach will be cheaper, with a maximum budget of around \$125 million for the sequestration work.

Kenneth Humphreys, chief executive of the FutureGen Alliance, says that the geology in Morgan County is both suitable and typical of what is readily available around the world. "We are focused on what could well be the workhorse solution," Humphreys says. C12's site is "interesting, but not nearly as common".

\section{WIDE SPREAD}

Outside experts say that it is hard to compare the sites until both have been fully characterized with modern seismic and other technologies. Although the type of structural containment proposed by $\mathrm{C} 12$ has advantages, it could be a disadvantage if a leak develops because all the $\mathrm{CO}_{2}$ would escape from one place, says Susan Hovorka, a carbon-sequestration expert at the University of Texas at Austin.

Similarly, although a lack of containment might translate into a larger plume, the dispersed $\mathrm{CO}_{2}$ is more likely to dissolve into

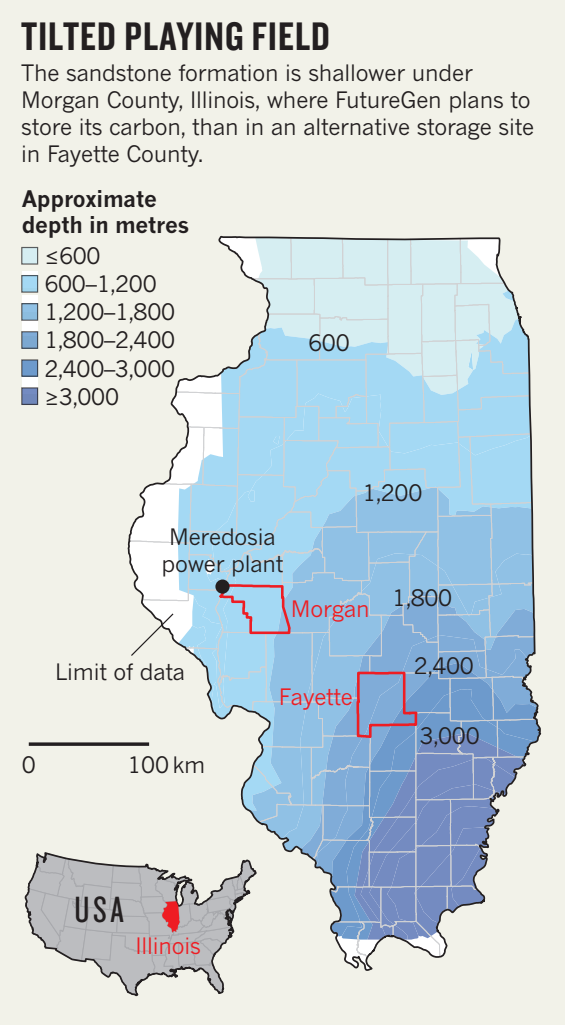

groundwater or to remain trapped in pore space, adds Robert Finley, who heads the Advanced Energy Technology Initiative at the Illinois State Geological Survey. "The C12 guys have one approach," Finley says, "but I don't think the validity of their arguments necessarily negates other approaches."

But C12 and its supporters argue that structural closure lessens the risk of liability if $\mathrm{CO}_{2}$ migrates into pore space for which the project has not secured legal access. "Let's start with a viable project where the risk is as low as possible," says Tony Meggs, a visiting engineer at the Massachusetts Institute of Technology in Cambridge, who chairs C12's board of directors. Humphreys says
"Let's start with a viable project where the risk is as low as possible." that FutureGen plans to sign lease agreements for subsurface rights with the landowners who own the land above the plume's location, but that will be more difficult if the plume spreads. When initially considering potential sites, FutureGen assumed a plume size of roughly 4 square kilometres. Humphreys has since acknowledged that the $\mathrm{CO}_{2}$ could end up spreading further, but the alliance won't know for sure until they have studied the geology of the site in detail. House says his team's modelling suggests that the gas could spread across 80-160 square kilometres in FutureGen's site.

House and his C12 colleagues are taking a broader approach, seeking legal access to all of the pore space in their reservoir. So far, C12 has signed leases with nearly 200 landowners, covering roughly $60 \%$ of the 100 square kilometres in their field, an area that could store roughly 13 times more $\mathrm{CO}_{2}$ than FutureGen expects to capture. Meanwhile, the company is working with Illinois lawmakers on extending to carbon storage the laws that apply to oil and gas fields, which grant legal access to the entire area once a certain percentage of the owners involved have signed on.

Some say that C12's business model simply didn't fit into the FutureGen project. James Wood, deputy assistant secretary for clean coal programmes at the Department of Energy, says that handing the storage half of the FutureGen project over to a commercial entity such as C12 might undercut the mission of the FutureGen Alliance partners, who are bolstering the more than $\$ 1$ billion in public money with roughly $\$ 244$ million of their own. "We don't want anybody skipping out halfway through the project," Wood says.

But for Schrag, that's further evidence that FutureGen is not being run the way it should be, which is as a commercial venture. He fears that FutureGen's current course could inflate costs and ultimately set the industry back. "This is the government's flagship demonstration of carbon capture and sequestration," Schrag says. "We really need it to work." 